\title{
POŻEGNANIE PROFESOR MARII DUDZIKOWEJ \\ PRZEZ FORUM MŁODYCH PEDAGOGÓW PRZY KOMITECIE NAUK PEDAGOGICZNYCH PAN
}

\section{Nasza Kochana Pani Profesor,}

Dziś, my - Młode Pedagożki i Młodzi Pedagodzy, odprowadzamy Cię w Twej ostatniej, ziemskiej drodze.

Chciałoby się powiedzieć dużo, żeby godnie pożegnać Panią Profesor. Żeby wychwycić wszystko to, co sprawiało, że była człowiekiem wyjątkowym, niepowtarzalnym.

Dziękujemy za każdy telefon późną nocą czy wczesnym rankiem i pytania: „Masz ołówek?”; „Jak sobie radzisz?”; „Nad czym teraz pracujesz?”. Za herbatę o poranku, czy gdy na nic już nie ma siły. Za każdą kartkę maszynopisu, referatu, wystąpienia, tekstu - przeczytaną w nocy, w przerwie, w pociągu, w parku, nad ranem. Za Letnią Szkołę Młodych Pedagogów, za Zespół Samokształceniowy i Samopomocy Koleżeńskiej Doktorów i za pracę z całym człowiekiem. Za myślenie czterema półkulami. Za tysiące godzin przegadanych. Za tytuł czy pomysł do pracy. Za stawianie sobie i nam wysoko naukowej poprzeczki. Za niezłomne bronienie wartości akademickiego etosu. Za głaskanie po głowie wtedy kiedy dobrze w życiu i gdy okropnie. Za wiersz i dedykacje na każdą okazję, na serca pocieszenie. Za żurek i ogórki kiszone z liściem czarnej porzeczki, tak pyszne po wielu godzinach pracy. Za korale czy chustkę. Za wspólny śmiech do łez, kiedy grubo po północy, a my przy pracy. Za książkę, której już albo jeszcze nigdzie nie ma. Za to, że każdy z nas czuł się wyjątkowo traktowany, że każda nasza rozmowa była ważna, rozwijająca... zarówno wtedy, gdy nas ganiłaś, czy chwaliłaś. Za to, że czytałaś swoje ukochane książki nie tylko dla siebie, ale - może przede wszystkim - dla innych. 
Pani Profesor pozostawia nam:

- własneksiążki(a w nich idee, których w pełni nie jesteśmy jeszcze w stanie odczytać);

- tropynaukowe;

- ludzi,zktórymi łączą nas wspólne działania;

- zadaniawarte kontynuacji;

- zdjęciawniezliczonych, niezwykłych sytuacjach;

- dedykacje(często z drogowskazem);

- niezapomnianewspomnienia wspólnej pracy i zabawy;

- słowawypowiedziane specjalnie dla nas;

- inspirujące idee;

- imperatywrozwoju - pracy nad sobą i pomagania innym;

- radośćtworzenia w pocie czoła;

- współczynnikhumanistyczny;

- odwagęwpisaniu o trudnych, ale palących problemach;

- skrzydlatesłowa, przesłania

Chciałoby się powiedzieć jeszcze więcej. Nieudolność języka, za którą nas Pani Profesor ganiła, nakazuje jednak powściągliwość.

Sztautynger powiedział:

„Nie żal odchodzić z tego świata, gdy tam róże i herbata”,

Ty dodawałaś:

Gdy tam książki, róże i herbata.

Do zobaczenia Nasza Kochana Profesor M.D. 